\title{
Domestication through the Centuries: Darwin's Ideas and Dmitry Belyaev's Long-Term Experiment in Silver Foxes
}

\section{La Domesticación a Través de los Siglos: las Ideas de Darwin y el Experimento a Largo Plazo de Dmitry Belyaev en Zorros Plateados}

\author{
Claudio J. Bidau
}

Laboratório de Biologia e Parasitologia de Mamíferos Silvestres Reservatórios Instituto Oswaldo Cruz/FIOCRUZ, Av. Brasil 4365-Manguinhos-21045 Rio de Janeiro, RJ, Brasil E-mail: bidau47@yahoo.com

\begin{abstract}
The problem of the origin of domestic animals and plants, and the means by which they were produced along human history, were of deep interest to Charles Darwin who considered domestic breeding 'one grand experiment' in evolution. In first place, he elaborated an analogy between artificial selection, by which breeders obtained desired characters in domestic species, and natural selection, the powerful force driving evolution in nature. At the same time, Darwin distinguished two processes within artificial selection: methodical and unconscious selection. He attached great importance to the latter since it could produce gradual unexpected changes in association with those characters that were consciously selected for. Although the analogy natural/artificial selection was initially controversial, it proved to be extremely useful in establishing the reality of natural selection as a key evolutionary factor. Nevertheless, the mechanisms involved in the process of domestication were largely unknown and posed intriguing problems such as the recurrent morphological, physiological, and behavioural similarities that appeared in widely different domestic animals. A distinguished Russian geneticist, Dmitry K. Belyaev, proposed that domestication was ruled by a process of 'destabilizing selection' affecting mechanisms of ontogenetic neuroendocrine control, either directly or indirectly in response to the appearance of a factor of stress. He also suggested that the key factor of domestication producing striking similar results in many species is selection for tameness. Thus, in 1959 he set up a long-term experiment of domestication of wild foxes (Vulpes vulpes) in which individuals were exclusively selected for tameness. Today, almost 50 generations later, near $100 \%$ of the experimental population actively seeks contact with humans. They exhibit a typical dog-like behaviour, which has been shown to be directly related to neuroendocrine ontogenetic modifications. Typical dog-like morphological, physiological and reproductive characteristics also appeared in the domesticated foxes. In this essay I review Darwin's ideas on domestication and then focus on Belyaev's still ongoing experiment and the consequences of its results for the theory of domestication and evolution.
\end{abstract}

KeYwords: Artificial selection, destabilizing selection, unconscious selection, tameness, Vulpes vulpes.

\section{RESUMEN}

El problema del origen de los animales y plantas domésticos, y los medios por los cuales fueron producidos a lo largo de la historia humana, eran de profundo interés para Charles Darwin que consideraba la domesticación como 'one grand experiment' en evolución. En primer lugar, elaboró una analogía entre la selección artificial, por la cual los criadores obtenían caracteres deseados en especies domésticas, y la selección natural, la poderosa fuerza conductora de la evolución en la naturaleza. Al mismo tiempo, Darwin distinguió dos procesos dentro de la selección artificial: selección metódica y selección inconsciente. Adjudicó gran importancia a esta última ya que podía producir cambios graduales inesperados asociados a aquellos caracteres conscientemente seleccionados. Aunque la analogía selección natural/selección

Pp. 55-72 en D’Elía, G. 2009. Una celebración de los aniversarios darwinianos de 2009. Gayana 73 (suplemento): 1-88. 
artificial fue inicialmente controvertida, demostró ser extremadamente útil para establecer la realidad de la selección natural como el factor clave de la evolución. De todos modos, los mecanismos involucrados en el proceso de domesticación eran ampliamente desconocidos y planteaban problemas intrigantes como las causas subyacentes a las recurrentes similaridades morfológicas, fisiológicas y comportamentales que aparecían en distintas especies de animales domésticos. Un distinguido genetista ruso, Dmitry K. Belyaev, propuso que la domesticación era regida por un proceso de 'selección desestabilizadora' que afecta los mecanismos de control neuroendocrino de la ontogénesis directa o indirectamente en respuesta a la aparición de un factor de stress. También sugirió que el factor clave de la domesticación, que producía sorprendentes resultados similares en muchas species, es la selección para mansedumbre (tameness). Entonces, en 1959, diseñó un experimento a largo plazo de domesticación de zorros silvestres (Vulpes vulpes), en el cual los zorros eran exclusivamente seleccionados para mansedumbre. Actualmente, casi 50 generaciones después, cerca del $100 \%$ de la población experimental busca contacto activo con los humanos exhibiendo un comportamiento típicamente perruno que ha sido directamente relacionado a modificaciones neuroendocrinas ontogenéticas. Los zorros domesticados tambien exhiben características morfológicas, fisiológicas y reproductivas típicamente perrunas. En este ensayo, paso revista a las ideas de Darwin sobre domesticación y luego me enfoco en el experimento, aún en marcha, de Belyaev y las consecuencias de sus resultados para la teoría de la domesticación y la evolución.

Palabras clave: Selección artificial, selección desestabilizadora, selección inconsciente, mansedumbre, Vulpes vulpes.

When we look to the individuals of the same variety or sub-variety of our older cultivated plants and animals, one of the first points which strikes us, is, that they generally differ much more from each other, than do the individuals of any one species or variety in a state of nature. When we reflect on the vast diversity of the plants and animals which have been cultivated, and which have varied during all ages under the most different climates and treatments, I think we are driven to conclude that this greater variability is simply due to our domestic productions having been raised under conditions of life not so uniform as, and somewhat different from, those to which the parent-species have been exposed under nature. ...It seems pretty clear that organic beings must be exposed during several generations to the new conditions of life to cause any appreciable amount of variation; and that when the organisation has once begun to vary, it generally continues to vary for many generations.

(Darwin 1859)

To Dmitry Belyaev, Liudmyla Trut and Pavel Borodin, for everything.

\section{INTRODUCTION}

Darwin's (1859) epoch-making publication, in which he proposed the most challenging hypothesis about the evolution of living beings, that of descent with modification through natural selection, did not begin with an account of the evidence about the former process, but on artificial selection and domestication of plants and animals.

\section{Origins And Concepts Of Domestication}

What is in fact 'domestication'? Darwin (1859, 1868) was perfectly aware that domestication was a very different thing than taming. For example, Asian elephants have been tamed for millennia, but never became a domestic species (Diamond 1998). For Darwin, domestication involved breeding in captivity and could occur without conscious effort, eventually producing an increase in fecundity/ fertility, the atrophy of certain organs or body parts and augmented plasticity, all facilitated by subjugation to man (see Price 1984).

Of course, the process of domestication is a process of adaptation to a man-made environment in which artificial selection, but also natural selection, play a fundamental role, which is reflected in the different definitions of domestication that have been proposed. Some selected examples are given below.

"Domestication involves the formation of a symbiotic relationship between man and other animals and plants", and also "The process of animal domestication involves adaptation - in particular, adaptation to man and the environment he provides".

(Rindos 1980). 
"Domestication is an evolutionary process involving the genotypic adaptation of animals to the captive environment"

(Price \& King 1968).

"...the contributions of both genetic change and the captive environment to the development of the captive phenotype."

(Ratner \& Boice 1975).

“...that process by which a population of animals becomes adapted to man and to the captive environment by some combination of genetic changes occurring over generations and environmentally induced developmental events reoccurring each generation."

(Price 1984).

"A domestic animal, in its most developed form [domestic phenotype, see Price 1984], shows four main characteristics: (1) its breeding is under human control; (2) it provides a product or service useful to humans; (3) it is tame; (4) it has been selected away from the wild type."

(Gentry et al. 2004).

“...a microevolutionary process and a form of cultural control over animals, implying that these creatures are forced to live and multiply in captivity; as a result they acquire domestic traits."

(Gautier 1990).

Domesticated animals and plants have accompanied humans since at least 10,000 or 13,000 years ago and the dog was probably the first domestic animal (Diamond 1998, 2002; Trut et al. 2009). Why humans began to domesticate animals for food is unclear, but some hypothesis have been advanced (Davis 2005; Zeder et al. 2006). However, in considering the origins of domestication, one problem has been repeatedly discussed and remains unresolved, that which Morey (1994) called "the issue of intentionality": how much of the domestication process can be attributable to conscious or deliberate human decisions? Is it possible, in the case of animals such as dogs, that domestication was at least in part "self-domestication"? That is adaptation of wild animals to new, man-made ecological niches. Certainly, natural and artificial selection may have both played a role at different or even at the same time during domestication (Trut 1999; Trut et al. 2004). The problem of unconscious selection originally proposed by Darwin $(1859,1871$; see below) must also be addressed to understand the nature of the physiological, morphological and behavioural changes experimented by species along the domestication process.

Furthermore, factors influencing domestication are multiple (see Price 1984 and Table 1). As discussed by Diamond $(1998,2002)$ only a very small number of animal species (about 10) have been completely domesticated and this may be due not only to the factors that acted during the process but also to what may be termed preadaptation to domestication (Price 1984; Clutton-Brock 1994; Cameron-Beaumont et al. 2002) which includes many behavioural characteristics (Table 1).

Although each domesticated form differs from its wild ancestor in a number of traits, many of which are peculiar to the involved organism, a number of typical domestication associated changes have been identified in many animal species (Trut 1999; O'Regan et al. 2005; Dobney \& Larson 2006; Jensen 2006). Darwin $(1859,1868)$ had already recognized some of these, such as changes in body size and proportions (for example the production of brachycephalic or chondrodystrophic domestic forms; Clutton-Brock 1999; Trut 1999; Jensen 2006) and changes in body coloration such as the piebald coat colour that occurs in all domesticated mammals (Trut 1999) or the appearance of curly or wavy hair (Trut 1999). Other common changes are the modification of the number of vertebrae producing for example, shorter tails, which occurs in various domestic breeds (Trut 1999) as well as internal changes including the reduction of some organs such as the brain (Kruska 1996; Jensen 2006).Finally, earlier sexual maturity and modification of reproductive cycles mediated by endocrine changes are common to all domestic species (Clutton-Brock 1999; Kuenzl \& Sascher 1999; Trut 1999) as well as the extension of the window of socialization during early growth (Belyaev et al. 1984; Trut 1999).

Most fundamental changes are those directly related to behaviour of domestic animals with direct implications to their symbiotic relationship with humans (Belyaev 1978; Price 1984; Clutton-Brock 1999; Trut 1999; Jensen 2006). 
TABLE I. A summary of features that influence the feasibility of domestication of animal species.

TABLA I. Resumen de las características que influencian la factibilidad de la domesticación de especies animales.

\begin{tabular}{|c|c|c|c|}
\hline \multicolumn{4}{|c|}{ Factors influencing the domestication process } \\
\hline Genetic mechanisms & $\begin{array}{l}\text { Biological environment } \\
\text { influence }\end{array}$ & $\begin{array}{c}\text { Physical environment } \\
\text { influence }\end{array}$ & $\begin{array}{c}\text { Behavioural } \\
\text { characteristics }\end{array}$ \\
\hline Inbreeding & Feeding and drinking & Shelter & Group structure \\
\hline Genetic drift & Predation & Space & Sexual behavior \\
\hline Artificial selection & Infectious agents, disease & & Parent-young interactions \\
\hline Natural selection & $\begin{array}{l}\text { Interaction with human } \\
\text { beings }\end{array}$ & & Responses to man \\
\hline $\begin{array}{l}\text { Relaxation of natural } \\
\text { selection }\end{array}$ & Social environment & & Alimentary habits \\
\hline & & & Habitat adaptability \\
\hline & & & Agility \\
\hline
\end{tabular}

Adapted from Price (1984).

Hundreds of domestic breeds of plants have been produced in the last 13,000 years (Hawksworth \& Kalin-Arroyo 1995; Diamond 2002). Coincident genetic and morphological changes in different domesticated plants have also been documented: gigantism, loss of natural dispersal and defense mechanisms, loss of seed dormancy, and polyploidyzation (Smartt \& Simmond 1995; Paterson 2002; Ross-Ibarra 2004). Recently, Ross-Ibarra (2004) demonstrated that in crop plants, domestication has also been accompanied by an increase in total recombination frequency; it is possible that the same phenomenon applies to some domestic animals (see below).

\section{DARWIN, DOMESTICATION AND ARTIFICIAL SELECTION}

\section{Darwin On Domestication}

The problem of animal and plant domestication was of fundamental importance for the development of Darwin's ideas about the theory of evolution by natural selection, and especially about the concept of natural selection itself and of populational (as opposed to typological) thinking in biology (Mayr 1982; Bowler 2009). Darwin's deep interest in domestication was shown not only by his profuse reading on these matters and his abundant correspondence with animal and plant breeders, but by his own experiments with pigeons (Secord 1981; Sol 2008; Nicholls 2009). The main point behind his interest in domestic breeds and races was the action of artificial selection in the modification of characters, and the factors affecting the process which suggestively, was first developed in published form, in the first chapter of the Origin (however, it has also been suggested that Darwin's interest in domestication had a second objective, that of disentangling the problems of heredity and variability [Bartley 1992]). His definition of artificial selection was as follows: "We cannot suppose that all the breeds were suddenly produced as perfect and as useful as we now see them; indeed in many cases we know that this has not been their history. The key is man's power of accumulative selection; nature gives successive variations; man adds them up in certain directions useful to him. In this sense he may be said to have made for himself useful breeds." (Darwin 1859). However, as demonstrated by a number of entries in his notebooks from 1836-1844 (Alter 2007a,b,c and references therein), his preoccupation with artificial selection and domestication occurred years before he started his first sketch of the Origin. 
TABLE 1. A summary of features that influence the feasibility of domestication of animal species.

TABLA 1. Resumen de las características que influencian la factibilidad de la domesticación de especies animales.

\begin{tabular}{|c|c|c|c|}
\hline \multicolumn{4}{|c|}{ Factors influencing the domestication process } \\
\hline Genetic mechanisms & $\begin{array}{l}\text { Biological environment } \\
\text { influence }\end{array}$ & $\begin{array}{c}\text { Physical environment } \\
\text { influence }\end{array}$ & $\begin{array}{c}\text { Behavioural } \\
\text { characteristics }\end{array}$ \\
\hline Inbreeding & Feeding and drinking & Shelter & Group structure \\
\hline Genetic drift & Predation & Space & Sexual behavior \\
\hline Artificial selection & Infectious agents, disease & & Parent-young interactions \\
\hline Natural selection & $\begin{array}{l}\text { Interaction with human } \\
\text { beings }\end{array}$ & & Responses to man \\
\hline $\begin{array}{l}\text { Relaxation of natural } \\
\text { selection }\end{array}$ & Social environment & & Alimentary habits \\
\hline & & & Habitat adaptability \\
\hline & & & Agility \\
\hline
\end{tabular}

Adapted from Price (1984).

Hundreds of domestic breeds of plants have been produced in the last 13,000 years (Hawksworth \& Kalin-Arroyo 1995; Diamond 2002). Coincident genetic and morphological changes in different domesticated plants have also been documented: gigantism, loss of natural dispersal and defense mechanisms, loss of seed dormancy, and polyploidyzation (Smartt \& Simmond 1995; Paterson 2002; Ross-Ibarra 2004). Recently, Ross-Ibarra (2004) demonstrated that in crop plants, domestication has also been accompanied by an increase in total recombination frequency; it is possible that the same phenomenon applies to some domestic animals (see below).

\section{DARWIN, DOMESTICATION AND ARTIFICIAL SELECTION}

\section{Darwin On Domestication}

The problem of animal and plant domestication was of fundamental importance for the development of Darwin's ideas about the theory of evolution by natural selection, and especially about the concept of natural selection itself and of populational (as opposed to typological) thinking in biology (Mayr 1982; Bowler 2009). Darwin's deep interest in domestication was shown not only by his profuse reading on these matters and his abundant correspondence with animal and plant breeders, but by his own experiments with pigeons (Secord 1981; Sol 2008; Nicholls 2009). The main point behind his interest in domestic breeds and races was the action of artificial selection in the modification of characters, and the factors affecting the process which suggestively, was first developed in published form, in the first chapter of the Origin (however, it has also been suggested that Darwin's interest in domestication had a second objective, that of disentangling the problems of heredity and variability [Bartley 1992]). His definition of artificial selection was as follows: "We cannot suppose that all the breeds were suddenly produced as perfect and as useful as we now see them; indeed in many cases we know that this has not been their history. The key is man's power of accumulative selection; nature gives successive variations; man adds them up in certain directions useful to him. In this sense he may be said to have made for himself useful breeds." (Darwin 1859). However, as demonstrated by a number of entries in his notebooks from 1836-1844 (Alter 2007a,b,c and references therein), his preoccupation with artificial selection and domestication occurred years before he started his first sketch of the Origin. 
essay on population by Malthus (Vorzimmer 1969b; Herbert 1971; Mayr 1982).

The analogy between artificial and natural selection was widely accepted by some, but also resulted controversial for others. Some of Darwin's supporters accepted the idea without questioning. For example Huxley (1860) wrote: "The Darwinian hypothesis has the merit of being eminently simple and comprehensible in principle, and its essential positions may be stated in a very few words: all species have been produced by the development of varieties from common stocks; by the conversion of these, first into permanent races and then into new species, by the process of natural selection, which process is essentially identical with that of artificial selection by which man has originated the races of domestic animals - the struggle for existence taking the place of man, and exerting, in the case of natural selection, that selective action which he performs in artificial selection." On the contrary, Alfred Russel Wallace, co-discoverer of the principle of natural selection, initially rejected the analogy because he considered artificial selection contrary to natural selection (Richards 1998; Camerini 2001; Porter 2004; Sarkar 2008). However, this discrepancy between both great scientists seemed to be not too serious. Wallace (1889) in the concluding paragraph of chapter IV of Darwinism wrote: "We thus see, that the evidence as to variation afforded by animals and plants under domestication strikingly accords with that which we have proved to exist in a state of nature. And it is not at all surprising that it should be so, since all the species were in a state of nature when first domesticated or cultivated by man, and whatever variations occur must be due to purely natural causes. Moreover, on comparing the variations which occur in any one generation of domesticated animals with those which we know to occur in wild animals, we find no evidence of greater individual variation in the former than in the latter. The results of man's selection are more striking to us because we have always considered the varieties of each domestic animal to be essentially identical, while those which we observe in a wild state are held to be essentially diverse."

The opponents of the analogy principle insisted in their attacks to Darwin during many years. Spencer (1893) spoke of "A parallelism that does not exist." Pearl (1917) after citing the four more important factors that, in his opinion, had contributed to the production of domesticated plants (i.e. improved domestication conditions, mutations, hybridization, and purification of mixed races by selective sorting) concludes that "It is to the overwhelming importance of one or a combination of these factors that the 'experience of breeders' points and not to Darwinian selection."

McAtee (1936), that cited Pearl (1917) as one of his main sources, criticized Darwin's analogy indicating that among other things: 1 . In artificial selection there is always a conscious selector while in natural selection, there is not (however, see below the discussion on Darwin's concept of 'unconscious selection'); 2. Artificial selection and its products are always for the benefit of the selector but in natural selection, for the benefit of the selected; 3. Man, the conscious selector, tries to make environmental conditions for the organisms to be selected, as favourable as possible, while nature "...Darwinians inform us, always puts hers [selected] through a merciless struggle for existence." He concluded that "Darwin tried to show how "natural selection" is similar to the art of breeders, but if he had ever contemplated the matter in reverse he would have realized that the methods he attributes to Nature are not imitated by man, and that if they were the achievements of artificial selection would have been quite impossible." and that, "If belief in "natural selection" depends on its analogy to artificial selection then that belief can scarcely prevail."

However, McAtee's objections do not invalidate the analogy between artificial and natural selection because although analogy is frequently (somewhat simplistically) defined as a comparison of processes or objects having a number of similar characteristics in common, a more rigorous definition explains analogy as "...a computational process of finding correspondences between complex structures that involve relations between objects and causal relations between relations." (Barnes \& Thagard 1997). In the case of Darwin's analogy, which these authors use as a well-known example, the target analogue that needs to be explained is the concept of natural selection from a comparison with the source analogue which in this case is artificial selection. Thus, "The explanatory power of the analogy derives from the correspondence between the high-level causal relations: just as human selection of traits 
causes new breeds to develop, so natural selection of traits causes new species to develop." (Barnes \& Thagard 1997).

However, the analogy still generates some diverging interpretations. As Ruse (1975) indicates, some Darwin scholars (i.e. Herbert 1971) do not consider that it played an essential role in the elaboration of Darwin's concept of natural selection, but that he first arrived to the idea after long years of gathering data and speculating about causes, and then after reading Malthus, he started seeing the correspondence between selection by man and selection by nature. However, Ruse (1975) indicates that this conclusion is incorrect and derives possibly, of a partial reading of Darwin's writing. As we have indicated above, by 1838, Darwin had read the pamphlets by Williamson and Sebright 21 years before the publication of the Origin, and maintained a permanent interest in the information provided by animal and plant breeders. In fact, from them he gathered right and wrong information, as Mayr (1982) indicates. The wrong one was a firm belief that simply putting an organism in domestication conditions would increase its variability (thus facilitating artificial selection): "I think we are driven to conclude that this greater variability is simply due to our domestic productions having been raised under conditions of life not so uniform as, and somewhat different from, those to which the parent-species have been exposed under nature" (Darwin 1859). However, one very important idea that Darwin obtained from the breeders was that of the individuality of each member of the domesticated population, idea which was fundamental to the development of the concept of natural selection (Mayr 1982).

Yet, other problems with interpretations of the analogy remain. As said above, Wallace initially rejected the analogy and it was because he considered it contrary to natural selection: the latter favoured fitness while artificial selection opposed fitness. Furthermore, artificial selection had never produced new species while natural selection was the efficient cause for the origin of species in nature. Interestingly, Darwin was very aware of this fact. When explaining natural selection by analogy with artificial selection, he was using a paradoxical argument: he could not demonstrate the causal efficacy of natural selection by comparing it with domestic breeding. However, this paradox can be resolved as Richards (1998) proposed: Darwin was in fact considering domestic breeding as 'one grand experiment' and not relying heavily on the similarities between artificial and natural selection, but on their differences (thus, in this sense, the explanation of the causal efficacy of natural selection would not be based strictly on an analogical argument). Richards (1998) indicates that "In the introduction to this later work [Variation of Plants and Animals under Domestication], Darwin describes domestic breeding as 'an experiment on a gigantic scale'. The value of this 'experiment' is what it reveals about the laws of organic nature. Consequently, the study of domestication is even more important than the study of nature, as Darwin tells us in the introduction to the Origin." In this sense, the importance of artificial selection is essentially experimental allowing us to select for a character and test its survival value. Adaptation in nature could be explained by reference to how domestication "adapts" an organism to the selector purposes: a heuristic approach to promote understanding of the process of natural selection.

One important problem faced by Darwin regarding domestication and artificial selection, was the paucity of data regarding the origin of the majority of domestic breeds. Darwin dealt with this problem considering that this lack of data was to be expected, just as the gaps in the fossil record were the expected result of the nature of evolutionary change. This second analogy however, has to be explained in a different form: gaps in the fossil record were due to its imperfection and to changes in adaptation (Mayr 1982), but obscurity in the origin of domestic breeds would be the result of the characteristics of the domestication process itself (Alter 2007b). In this sense, Darwin (1868) wrote: "All that we know, and, in a still stronger degree, all that we do not know, of the history of the great majority of our breeds, even of our more modern breeds, agrees with the view that their production... has been almost insensibly slow." This was of utmost importance in Darwin's thinking and Darwin's analogy: according to the theory, organic evolution through natural selection is also an insensibly slow process.

\section{Darwin's Idea Of “Unconscious Selection" \\ "At the present time, eminent breeders try by methodical selection, with a distinct object}


in view, to make a new strain or sub-breed, superior to anything existing in the country. But, for our purpose, a kind of Selection, which may be called Unconscious, and which results from every one trying to possess and breed from the best individual animals, is more important."

(Darwin 1859, p.34)

The previous excerpt from the first chapter of the Origin clearly shows that Darwin, when considering the processes involved in breeding and domestication, differentiated between "methodical selection" (what we would now term, typical 'artificial selection'; the latter term was created by Balfour Stewart and Peter Guthrie Tait [Tait 1871; Stewart \& Tait 1886]) and "unconscious selection" which he defined as: “...is that which follows from men naturally preserving the most valued and destroying the less valued individuals, without any thought of altering the breed; and undoubtedly this process slowly works great changes. Unconscious selection graduates into methodical, and only extreme cases can be distinctly separated; for he who preserves a useful or perfect animal will generally breed from it with the hope of getting offspring of the same character; but as long as he has not a predetermined purpose to improve the breed, he may be said to be selecting unconsciously." Then, Darwin of course, refers to natural selection: "With domestic productions, natural selection comes to a certain extent into action, independently of, and even in opposition to, the will of man ". However, the concept of unconscious selection had already appeared in his "Essay" (Darwin 1844) and even in his "Pencil Sketch" of 1842 (see Alter 2007a), but not earlier.

As several authors have emphasized, the concept of unconscious selection is of great importance for several reasons (Alter 2007a; Zohary 2004; Heiser 1988). The act of domestication introduces a wild animal in a new environment that is ecologically different from the original one. Thus, characteristics that were adaptive in the wild have less fitness. For survival in the new ecological milieu, new adaptations must be selected automatically (Zohary 2004). This situation leads to the build-up of socalled 'domestication syndromes' characteristic of the system in which the species are introduced. This unconscious selection continues during all the domestication process, basically independently from the will of the domesticator. Heiser (1988) summarized the changes produced by unconscious selection in domesticated plants (those in animals will be discussed in the next section). Apart from changes in the breeding system, Heiser (1988) lists: 1. loss of natural dispersal mechanisms, 2. Even and rapid seed germination, 3. Larger propagules, 4. Simultaneous ripening, 5. Loss of mechanical means of protection, 6. Colour changes in fruit and seed and, 7. Loss of toxicity or bitterness.

In discussing how Darwin arrived to the notion of unconscious selection, Alter (2007a) highlights a very important issue: "Darwin eventually perceived that an application of these themes to domestic breeding would resonate with his notion that species in nature had developed in a gradual and ad hoc fashion, not according to a pre-determined plan." That is, unconscious selection was extremely relevant to the theory of evolution by natural selection than (probably) methodical selection was. This notion is reinforced by the fact that Darwin was aware that unconscious selection could not only result in unexpected changes within a single lineage of a domestic breed, but also produce the splitting and divergence of the original lineage (Alter 2007a). Furthermore, unconscious selection bridged the time differential between evolution in nature, which required vast periods of time and the results of breeding by methodical selection, that were seen in few generations: the long time of existence of many familiar breeds indicated that a kind of gradual change had occurred under domestication itself independently of methodical selection.

The concept of divergent unconscious selection, as Alter (2007a) has argued, developed in Darwin's mind simultaneously with the idea of sexual selection (especially to explain racial differences in man through differential standards of attractiveness in different populations). However, both concepts were only treated together in The Descent of Man... (Darwin 1871) (Alter 2007a). Finally, it is interesting to note that in a letter to Chauncey Wright of June 3, 1872 (Darwin 1958) in discussing the origins of language, Darwin wrote: "As your mind is so clear, and as you consider so carefully the meaning of words, I wish you would take some incidental occasion to consider when a thing may properly be said to be effected by the will of man. I have been led to the wish by reading an article by your 
Professor Whitney versus Schleicher. He argues, because each step of change in language is made by the will of man, the whole language so changes; but I do not think that this is so, as man has no intention or wish to change the language. It is a parallel case with what I have called "unconscious selection," which depends on men consciously preserving the best individuals, and thus unconsciously altering the breed". Wright (1872) agreed with Darwin's idea.

\section{INTERLUDE}

After Darwin's initial considerations, the causes of phenotypic and physiological changes during the domestication of wild species remained obscure during a full century. Why recurrent changes occurred in so different species? Why and how domesticated species became symbiotic with Homo sapiens? Was it unconscious or methodical selection? In the twentieth century (1959) an impressive experiment started in Siberia by Dmitry Belyaev. That is the subject of the next section of this paper.

\section{THE GENIUS IN THE FOX FARM}

Dmitry Konstantinovich Belyaev (Figs. 1, 2) was born in July 17, 1917 (Protasovo, Kostroma province) during the First World War (1914-1918) and only a few months before the October Bolshevik Revolution. He was the fourth and youngest son of a respected family (his father, a priest, Konstantin Pavlovich was reputed as the most learned man in the village), which valued education (Trut et al. 2007).

Early in his life Dmitry Belyaev was introduced into a great intellectual atmosphere of Russian genetics. His elder brother (18 years older) Nikolai was a prominent geneticist himself working along with Sergei Sergeievich Tchetverikov (18801959), a pioneer in population genetics, which in turn strongly influenced Theodosius Dobzhansky (1900-1975) and Nikolai Konstantinovich Koltsov (1872-1940), who advanced the hypothesis that hereditary characters where inherited through a double-stranded giant molecule present in each chromatid of chromosomes, one of which served as a template for the synthesis of a complementary one (Soyfer 2001).

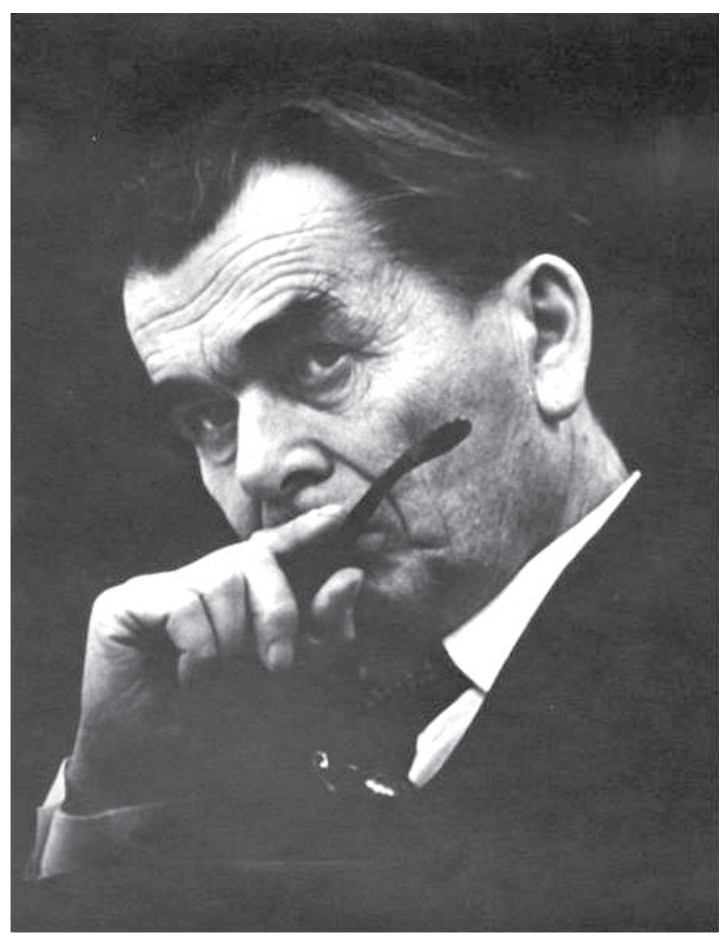

Figure 1. Dmitry Konstantinovich Belyaev (1917-1985).

Figura 1. Dmitry Konstantinovich Belyaev (1917-1985).

It was a very fruitful period for Russian genetics and a very hard time to Russian geneticists. Koltsov was arrested and underwent trial for anti-soviet activities but was liberated after an appeal to Stalin by Maxim Gorki. However, campaigns against Koltsov and Nikolai Vavilov (both geneticists at the Soviet Academy of Sciences) led by T. Lysenko and his supporters, resulted in Koltsov death in 1940. Nikolai Ivanovich Vavilov (born in 1887), one of the greatest geneticists, plant breeders and geographers of the 20th Century, was imprisoned and sentenced to death in 1940. Although his sentence was changed to 20 years in prison, Vavilov died in 1943 from dystrophy (faulty nutrition of muscles, leading to paralysis; that is, from hunger [Zakharov 2005; Pringle 2008]). Tchetverikov had also been arrested and exiled in 1929, shortly before Stalin's persecutions; although he lived until 1959 his work was never the same (Adams 1998; Dobzhansky 1998). Timofeef-Ressovsky, who was working in Germany, after Russians entered Berlin was arrested, liberated, and arrested again to be sent to the Gulag until 1955 (Medvedev 1982). The elder brother of Dmitry Belyaev, Nikolai Konstantinovich, was also 
arrested in August 1937, and executed without trial in November 10 of the same year (Asrguthynskaya \& Zakharov 2005). This infamous persecution resulted in an almost abolition of orthodox genetics and Darwinism during decades (Vucinich 1988).

Soon after graduation from the Ivanovo Agricultural Institute in 1938, Dmitry entered the Department of Fur-Bearing Animals of the Central Research Laboratory. The genetic and biological background provided by his brother proved to be incredibly fruitful. Although military service to which he was called in 1941 during the Second World War (in which he was wounded and decorated with several military orders [Trut et al. 2007]) interrupted his scientific research, Dmitry reassumed after demobilization his activities at the Central Research Laboratory (Department of Fur Bearing Animals) affiliated with the Ministry of Foreign Trade, where he became involved in breeding of silver-black foxes and mink. At that time Mendelian genetics and Darwinism were still being persecuted; however, Dmitry's dissertation was on "The variation and inheritance of silver-colored fur in silver-black foxes", an announcement of what was to come. During the hard years that followed the infamous Session of the All-Union Russian Academy of Agricultural Sciences, Belyaev maintained his firm beliefs in Mendelian genetics and evolution and sided with such extraordinary biologists as Boris Astaurov (1904-1974) and many other scientists, although he was much younger than them (Trut et al. 2007). Nevertheless, because of his strong support of Mendelian genetics, Belyaev eventually was demitted from his position as Head of Department (Trut et al. 2007; Trut 1999).

From 1958, when the political view on genetics was slowly reverting, to the end of his life in 1985, Dmitry worked at the USSR Academy of Sciences (Siberian Division). There, he became in 1963 Director of the Department of Animal Genetics of the Institute of Cytology and Genetics (through an invitation from N.P. Dubinin); position that he held until the end of his life.

Belyaev's Ideas On Domestication And The Farm Fox EXPERIMENT

One of Belyaev's main scientific interests was that discussed in the first part of this essay: the origin and consequences of domestication, especially the recurrent similar changes that have appeared during the course of the process in widely different species. Although a good deal of scientific information was available on existing domestic plant and animals since Darwin's day, the real nature of domestication and the concurrent morphological and physiological changes, were virtually unknown, Thus, at his research post at the Institute of Cytology and Genetics in Novosibirsk, Siberia, Belyaev started an extraordinary long-term experiment in domestication using a completely new model: the Red or Silver Fox (Vulpes vulpes).

This species has one of the largest geographic distributions of mammals; it distributes in most of Canada and the United States, northern Asia, and almost all of Eurasia (Larivière \& PasitschniakArts 1996; Nowak 1999; Macdonald \& Reynolds 2004). It inhabits deep forest, arctic tundra, open prairie, farmland, and even large cities as London or Paris. As its common name suggests, its fur is predominantly reddish-brown, but there is a naturally occurring black morph known as the Silver Fox which comprises about $10 \%$ of the species (Nowak 1999). Foxes are much appreciated for their fur especially the silver morph and thus, apart from traditionally being hunted (although $V$. vulpes has also been much persecuted for being considered a pest by poultry farmers), they are bred in fox-farms. Breeding has not involved domestication except in the case we will discuss here.

Belyaev's main hypothesis was that changes that appeared in domesticated animals were the consequence of genetic modifications that occurred in the course of artificial selection. These changes would thus be the result of Darwinian 'unconscious selection'. Furthermore, Belyaev considered that the main selective factor in triggering these changes was not selection for morphological characteristics, but essentially for what he termed 'tamability' selection for 'tameness' and a friendly relationship with humans. Belyaev viewed tameness as the key adaptive factor in establishing the symbiotic relationship between the animals being domesticated and humans (Belyaev \& Trut 1964a, b, 1982; Belyaev 1969, 1974, 1978; Trut 1999). As Trut (1999) said: "Because behaviour is rooted in biology, selecting for tameness and against aggression means selecting for physiological changes in the systems that govern 
the body's hormones and neurochemicals. Those changes, in turn, could have had far-reaching effects on the development of the animals themselves, effects that might well explain why different animals would respond in similar ways when subjected to the same kinds of selective pressures."

A central theme of Belyaev's hypothesis was to discover 'What is the nature and the essence of the selection that serves as the driving force of domestication? What is the form, or rather the effect, of this selection?' (Belyaev 1978). As we will see in the description of Belyaev's farmfox experiment (continued today by his disciple Lyudmila Nikolaevna Trut), Belyaev hypothetized that concerted changes during domestication arose from a new type of selection which he termed ‘destabilizing' (Belyaev 1978; Trut 1988).

The striking coincidence of the morphological changes that undergo most domesticated mammals (and non-mammals) prompted Belyaev's hypothesis (see Trut 1999 for a summary of these changes, many of which had previously been noted by Darwin $[1859,1868])$. Of course, other non-morphological changes have also been recurrent in domestic animals, especially the disappearance of seasonal rhythms of reproduction, which characterize almost all wild animals, especially those from temperate areas (Trut 1999). This last feature is very difficult to explain because 'the heritability of the traits characteristic of the seasonal rhythm of activity of wild animals is practically zero' (Belyaev \& Trut 1964a,b; Belyaev 1978). He also noted that in all domestic animals fertility greatly increases.

Then, he hypothesized that given that one of the main aspects of animal domestication is the elimination of aggression and fright to facilitate human-animal symbiosis, this should have produced significant behavioural responses (i.e. tame animals) through destabilizing selection. How does this selection act? According to Belyaev (1978), it mainly affects the mechanisms of neuroendocrine control of ontogenesis, either directly or indirectly. Selection becomes destabilizing in response to the appearance or the strengthening of a stressful factor. "One may think therefore that stress is one of the important factors accelerating the evolution of life, especially at the highest level of organization where neuro-hormonal controls on ontogeny are most effective" (Belyaev 1978). In this form, destabilizing selection would disrupt systems of genetic activation or inactivation during ontogenesis that were stable before the initiation of domestication. The result would be an increase in genetic variation that then become subjected to new selective forces (Belyaev1974). Then, the similar consequences of domestication and destabilizing selection in all animals would be the result of selection for a single and fundamental factor: tame behaviour. This coincidence is to be expected since mammals from different taxonomic groups share similar regulatory hormonal and neurochemical mechanisms (Trut 1999). Of course, tamability should have a genetic basis (at least partly) so that the trait can be selected, and this was demonstrated by Belyaev's group in a series of studies during the 60's and indicated that $35 \%$ of the behavioural responses of foxes to humans, have a genetic basis (Trut 1999).

\section{The Nature Of The Farm-Fox Experiment}

The original setup of Belyaev's experiment (origin of silver foxes, crossings, etc.) have been described elsewhere (Trut 1999; Trut et al. 2004, 2009; Kukeva et al. 2006). It is important to understand how the selection process was initiated and continued. To test Belyaev's hypothesis it was essential that silver foxes were only selected for tameness and no other trait.

How was this performed? A series of standardized tests were designed to evaluate the response of 1-month old pups to the experimenter and another pups. These tests were repeated monthly and at about seven months, pups were included in one of three classes. Class I individuals were very friendly to experimenters; Class II animals could be handled but did not show emotional response to humans, and Class III included those pups that if handled were aggressive and bite the experimenters. Interestingly, after a short number of generations Belyaev's team had to add a fourth class (IE), the domesticated elite (Trut 1999). IE members are not only friendly to humans but they also eagerly seek human contact. Frequency of this group increased steadily through the years: starting with $1.8 \%$ in the sixth generation, by 1999 , almost $80 \%$ of the foxes belonged to this class (Trut 1999) and by 2006, almost $100 \%$ of the domesticated population belonged to the elite (Kukekova et al. 2006). The pressure of 
selection was very rigorous at the beginning of the experiment: less than $10 \%$ of the tamest individuals of every generation were used as parents of the next generation (Trut 1999; Trut et al. 2004; Kukekova et al. 2006). This strong selection procedure resulted, in just 50 years, in a population of domesticated foxes with behavioural characteristics similar to the domestic dog (Fig. 2).

According to Trut et al. (2004), glucocorticoids may be involved in the determination of development rates and changes of these rates during domestication. This conclusion comes from the fact that during the experiment, comparisons of pups from the selected and unselected populations, revealed that in the latter at 45 days of age the fearful response to humans appears, exploratory behaviour of a new environment decreases and there is a sharp increase in glucocorticoid content in the peripheral blood. On the contrary, in domesticated pups of the same age the fearful response does not appear, exploratory activity is not diminished (in fact, this does not occur even at three months of age) and glucocorticoid content is not increased (Trut et al. 2004). Thus, in domesticated foxes, the period of socialization is significantly increased (also, play activity extends into adulthood) (Trut 1999; Trut et al. 2004, 2009; Kukhekova et al. 2006).

Glucocorticoids may influence the timing of development by, for example, inhibiting cell proli-

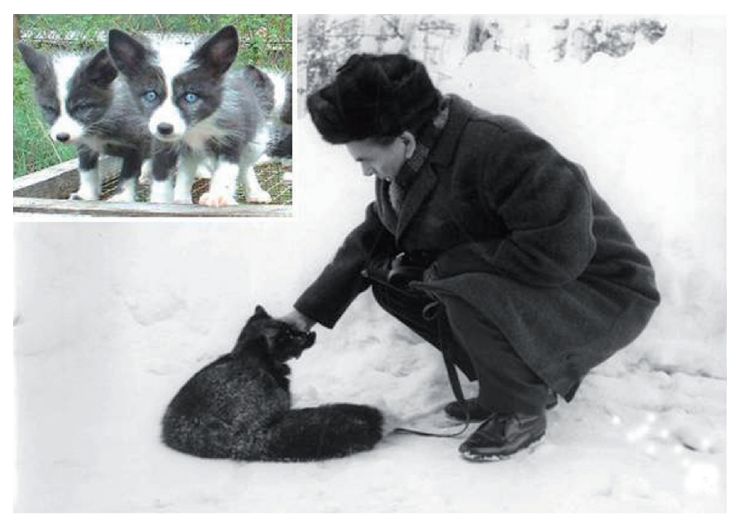

FIGURE 2. Belyaev at his institute playing with one of his domestic foxes (note the white tipped tail). Insert: two piebald pups carrying the Star gene.

FIgURA 2. Belyaev en su instituto jugando con uno de sus zorros domésticos (notar la punta de la cola blanca). Inserto: dos cachorros manchados portadores del gen Star. feration thus promoting differentiation. Comparative studies of the hypothalamic-pituitary-adrenal (HPA) axis support this hypothesis (Gulevich et al. 2004; Trut et al. 2009): basal cortisol levels decreased by three to five in tame foxes during the selection process by generation 45 . In fact, HPA axis activity is reduced at all levels in tame foxes, which strongly suggests that genes regulating plasma glucocorticoids are the target of selection for tameness (Trut et al. 2009). It is also important to note that domestication also affects the developmental neurotransmitter systems. For example, differences between tame and non-tame foxes in the activities of two key enzymes in serotonin metabolism, monoamine oxidase and trytophan hydroxylase, were demonstrated as well as increased serotonin levels in tame foxes brains; serotonin has well known inhibitory effects on aggressive behaviour (Popova 2006; Trut et al. 2009). Results on foxes are concordant with those obtained in rats that have been subjected to an analogous process of domestication (Albert 2008; Albert et al. 2008).

Behavioural changes in domesticated foxes were accompanied by striking morphological and physiological changes: tame fox pups respond to sound two days earlier and open their eyes one day earlier than non selected fox-farm ones (Trut 1999). From the 8 th to the 10 th generations, a series of morphological novelties started to appear. These included at first, changes in coat colour corresponding to loss of pigment in areas of the body (piebald pattern) including a star-shaped spot in the face which is frequent in other domestic animals such as dogs, horses, cows, etc (see Fig. 3 in Trut 1999). This pattern was demonstrated to be due to the Star gene (Belyaev et al. 1981). This gene controls the migration rate of melanoblasts (Prasolova \& Trut 1993) during embryonic development to potential pigmented zones of the epidermis. In Star carriers (Fig. 2) (heterozygotes and homozygotes) this migration is delayed, which may lead to the death of melanoblasts in certain regions, producing lack of melanocytes and thus, of pigmentation.

Then, in successive generations of selection further changes arose: floppy ears (a characteristic present in all domestic mammals but absent in all wild ones except elephants), rolled and shorter tails, shorter legs, and underbites or overbites (Trut 1999; Kukhekova et al. 2006). All these traits, including 
piebald colour, are dog-like characteristics. A comparison of the frequencies of some of these state characters in tame and non-tame foxes is given in Table 2; note that in all cases, domesticated foxes show a dramatic increase in frequency of all dog-like traits. Interestingly, a correlation between those values (originally expressed in individuals displaying the trait per 100,000 individuals), are highly significantly correlated $(\mathrm{r}=0.95, p=$ 0.0022 ) suggesting a single cause for the increase in frequency of all of them: selection for tameness, a behavioural characteristic. It is very important to stress that this novel characters could not be acquired normally by inbreeding since the farmfox experiment was carefully devised to avoid it (probability of acquiring a trait through inbreeding was 0.02-0.07; Trut 1999). Furthermore, some of the new traits are not recessive being expressed in heterozygous condition. In addition, the results are not caused by the disruption of polygenes for quantitative characters because they appeared repeatedly in different domestic species breeds by different people in different circumstances, and the effects of the novel characters are not harmful. Furthermore, some reproductive characteristics, including earlier sexual maturity, larger litters, and a longer mating season, have undergone a correlated change in domestic foxes that is note seen in unselected individuals (Trut 1999).

A very interesting development of this long-term experiment concerns $\mathrm{B}$ chromosomes and rate recombination. Silver foxes are polymorphic for 0 to 10 small B chromosomes. Almost all foxes carry them and these supernumerary chromosomes are mitotically unstable; thus, different cell clones of the same individual may carry different numbers of Bs (Belyaev et al. 1974; Switonski et al. 1987). The silver fox Bs are also exceptional because they are similar to those carried by another canid, the raccoon dog Nyctereutes procyonoides; both species being separated by about $12.5 \mathrm{MY}$ of independent evolution (Shi et al. 1988). Furthermore, it has recently been demonstrated that in both species, Bs carry an active copy of an autosomal gene, the proto-oncogene C-KIT, a case unique in mammals (Yudkin et al. 2007). It has also been recently shown using immunofluorescence techniques, that Bs genetically recombine among themselves (Borodin et al. in preparation). In the context of domestication we also recently demonstrated that domesticated foxes have a higher mean number of B chromosomes than unselected ones (3.92 vs $2.72 ; p<0.001$ ) with a maximum of $10 \mathrm{Bs}$ per cell in the former and 6 in the latter (Borodin et al., in preparation). This observation is relevant in the context of another theory involving domestication. It has been proposed that a high recombination is a preadaptation to domestication because it would facilitate response to strong selection (Gornall 1983). Alternatively, a second hypothesis predicts an increment in recombination through domestication (Rees \& Dale 1974; Burt \& Bell 1987; Otto \& Barton 2001). This was suggested because theory and simulations predict that selection generally favours an increased recombination rate during periods of rapid evolutionary change, as in domestication. Recently, Ross-Ibarra (2004) corroborated the second hypothesis for domesticated plants. In the context of fox B chromosomes, the observation of an increment during domestication is important for various motives; Bs may add variability to the carrier because of their sole presence through different cellular effects. One of these effects repeatedly observed in plant and animals, is an increase in genetic recombination in the cells where they are present. We did not found differences in autosomal recombination frequency between selected and nonselected foxes, but selected ones showed an increase of between-cell variability of recombination with number of Bs, which would agree with Ross-Ibarra's (2004) results.

Although outside the scope of this essay, it is relevant to mention that in recent years, the domesticated silver fox is being increasingly used to study the genetic basis of behavioural and morphological changes that occur during the process of domestication (Kukekova et al. 2004, 2006, 2007, 2008; Lindberg et al. 2005; Trut et al. 2006).

The domestication of modern dogs from Canis lupus ancestors began more than 12,000 years ago. Belyaev and his disciples produced similar result in silver foxes in just 50 years. By carefully theorizing with solid Darwinian bases in a dark period of Soviet science, Belyaev produced one of the most impressive experiments in the history of evolutionary biology and contributed not only to the comprehension of how selection operates during domestication but, through his proposal of destabilizing selection due to the appearance of 
stressful factors (for example, introduction into a new environment and strong methodical selection), he helped to understand how rapid evolution may occur in nature.

\section{CONCLUSIONS}

Domestication of animals and plants, a phenomenon of uncertain origins, has accompanied humanity's cultural evolution for thousands of years. Breeding of domestic species and varieties has been of paramount importance not only for the production of food and fiber but also due to its role in the development of the most fundamental of the biological theories: evolution by natural selection. To reach the conclusion that natural selection was the central driving force of evolution of living beings, Darwin relied in abundant information from diverse sources such as geology, paleontology, biogeography, comparative anatomy, etc. But one of the basic foundations of the theory was his analogy between artificial and natural selection. As we have discussed, the nature and value of this analogy has been controversial but its usefulness in establishing the reality of the theory of natural selection is undeniable. However, in considering Darwin's discussion on domestication and artificial selection, two points are worth noting: first, Darwin developed his concept of unconscious selection to explain why, within the same domestic species, different populations could develop distinct characteristics despite being subjected to similar breeding procedures. This was relevant because it explained divergence, and divergence was central to Darwin's explanation of how natural selection operated in nature and produced speciation and evolution. The other question that intrigued Darwin was that of the striking similarities developed by widely different domesticated animals and plants. Darwin did not have a clear answer to this puzzle. The answer started to became clear exactly one hundred years after the publication of the first edition of the Origin of Species: Belyaev's farm-fox experiment. Darwin would have truly appreciated it.

Thus this year, we are not only celebrating two centuries of Darwin's birth and 150 years of the Origin, but also 50 years of the beginning of one of the most extraordinary and fruitful experiments in evolutionary biology.

\section{ACKNOWLEDGMENTS}

I am extremely grateful to Dr. Guillermo D’Elía (Universidad de Concepción, Chile) for his kind invitation to write this essay. To Dr. Pavel Borodin (Institute of Cytology and Cytogenetics, Novosibirsk, Russia), for his encouragement, his useful commentaries, invaluable Russian bibliography, critical reading of the manuscript and especially, for having me introduced to the fascinating world of Belyaev's foxes. And to him and Prof. Lyudmyla Trut for the fine Belyaev's photographs. I also want to thank my wife, Dr. Rocio Hassan, for the critical reading of the manuscript. The financial support of CNPq, FAPERJ and FIOCRUZ is gratefully acknowledged.

\section{BIBLIOGRAPHY}

Adams, M.B. 1998. Sergei Chetverikov, the Kol'tsov Institute, and the Evolutionary Synthesis. In: The evolutionary synthesis. Perspectives on the unification of biology (Eds. Mayr, E. \& Provine, W.E.), pp 262-279. Harvard University Press, Cambridge, MA.

Albert, F.W. 2008. Uncovering the genetic basis for tameness - a research strategy. Gerald of VOGIS 12(1/2):19-23

Albert, F.W., O. Shchepina, C.Winter, H. Römpler, D. Teupser, R. Palme, U. Ceglarek, J. Kratzsch, R. Sohr, L.N. Trut, J. Thiery, R. Morgenstern, I.Z. Plyusnina, T. SchöNeBerg \& S. PäÄBo. 2008. Phenotypic differences in behaviour, physiology and neurochemistry between rats selected for tameness and for defensive aggression towards humans. Hormones and Behaviour 53(3): 413421.

Alter, S.G. 2007a. Separated at birth: the interlinked origins of Darwin's unconscious selection concept and the application of sexual selection to race. Journal of the History of Biology 40 (2):231-258.

Alter, S.G. 2007b. The advantages of obscurity: Charles Darwin's negative inference from the histories of domestic breeds. Annals of Science 64(2):235250.

Alter, S.G. 2007c. Darwin's artificial selection analogy and the generic character of "phyletic" evolution. History and Philosophy of Life Sciences 29(1):5781.

Asrgutynskaya, S.V. \& I.K. ZhaKarov. 2005. Nikolai Konstantinovich Belyaev. Gerald of VOGIS 9(2):99-105 (in Russian).

Barnes, A. \& P. Thagard. 1997. Empathy and analogy. Phylosophical Review 36 (4):705-720.

BartLey, M.M. 1992. Darwin and domestication: studies 
on inheritance. Journal of the History of Biology 25(2):307-333.

BeLyaEv, D.K. 1969. Domestication of animals. Science Journal (U.K.) 5:47-52.

BeLYaEv, D.K. 1974. Some questions of stabilizing and destabilizing selection. In: History and theory of the evolutionary doctrine (in Russian). Leningrad, pp. 76-84.

BeLYAEv, D.K. 1978. Destabilizing selection as a factor in domestication. The Journal of Heredity 70 (5):301-308

Belyaev, D. K., A.O. Ruvinsky, \& L.N. Trut. 1981. Inherited activation-inactivation of the star gene in foxes. The Journal of Heredity 72 (4):267-274.

Belyaev, D. K. \& L.N. Trut. 1964a. Behaviour and reproductive function of animals. I. Correlation of behaviour type with the time of reproduction and fertility. Bulletin of the Moscow Society of Naturalists Biological Series (in Russian) 69(3):5-19.

Belyaev, D. K. \& L.N. Trut. 1964b. Behaviour and reproductive function of animals. II. Correlated changes under breeding for tameness. Bulletin of the Moscow Society of Naturalists Biological Series (in Russian) 69(5): 5-14.

Belyaev, D. K. \& L.N. Trut. 1982. Accelerating evolution. Science in the USSR 5:24-29, 60-64.

Belyaev, D.K., I.Z. Plyusnina, \& L.N. Trut. 1984. Domestication in the silver fox (Vulpes fulvus desm.)-changes in physiological boundaries of the sensitive period of primary socialization. Applied Animal Behaviour Science 13(4):359-370.

Belyaev D.K., V.T. Volobuev, S.I. Radzhabli \& L.N. TRUT. 1974. Supernumerary chromosome polymorphism and mosaicism in silver foxes. Genetika (in Russian) 10(1): 58-67.

Bowler, P.J. 2009. Darwin's originality. Science 323(5911):223-226.

Burt, A. \& G. BeLl. 1987. Mammalian chiasma frequencies as a test of two theories of recombination. Nature 326 (6115):803-805.

CAmerini, J.R. [ed.]. 2001. The Alfred Russel Wallace reader: a selection of writings from the field. Johns Hopkins University Press, Baltimore. 304 pp.

Cameron-Beaumont, C., S.E. Lowe \& J.W.S. Bradshaw. 2002. Evidence suggesting preadaptation to domestication throughout the small Felidae. Biological Journal of the Linnean Society 75(3):361-366.

Cleveland, D.A. \& D. Soleri. 2007. Extending Darwin's analogy: bridging differences in concepts of selection between farmers, biologists, and plant breeders. Economic Botany 61(2):121-136.

Clutton-Brock, J. 1992. The process of domestication. Mammal Review 22(2):79-85.

Clutton-Brock, J. 1994. The unnatural world. Behavioural aspects of humans and animals in the process of domestication. In: Animals and Human Society. Changing Perspectives (Eds. Manning, A. \& J. Serpell), pp. 23-35. Routledge, London-New York.
Clutton-Brock, J. 1999. A natural history of domesticated mammals. Cambridge University Press, Cambridge. 238 pp.

Cornell, J.F. 1984. Analogy and technology in Darwin's vision of nature. Journal of the History of Biology 17(3):303-344.

DARWIN, C. 1839. Questions about the breeding of animals. Privately published.

DArwin, C. 1844. Essay. First published in Darwin, F. 1909. The foundations of the origin of species, by Charles Darwin. Cambridge University Press, Cambridge. 273 pp.

Darwin, C. 1857. Letter to Asa Gray, September $5^{\text {th }}$, 1857. Reprinted In: Charles Darwin`s Letters: A Selection 1825-1859 (Ed. Burkhardt, F), pp. 177179. Cambridge University Press, New York.

DARWIN, C. 1859. On the origin of species by means of natural selection. 1st Edit. John Murray, London. $\mathrm{x}+502$ pp. 1 fig.

DARwIN, C. 1868. The variation of animals and plants under domestication. John Murray, London. I, xiv +473 pp. 43 figs, II, $x+495$ pp.

DARWIN, C. 1871. The descent of man and selection in relation to sex. Murray, London. xvi $+693 \mathrm{pp}$.

DARwIN, C. 1887. The life and letters of Charles Darwin, including an autobiographical chapter edited by his son Francis Darwin in two volumes. Vol. II. John Murray, London. iv +394 pp.

DARwIN, C. 1958. The autobiography of Charles Darwin. (ed., Barlow, N. ). Collins, London. 253 pp.

DAVIS, S.J.M. 2005. Why domesticate food animals? Some zoo-archeological evidence from the Levant. Journal of Archeological Science 32(9):14081416.

DiAmOND, J. 1998. Guns, germs and steel. A short history of everybody for the last 13,000 years. Vintage, London. 480 pp.

Diamond, J. 2002. Evolution, consequences and future of plant and animal domestication. Nature 418 (6898):700-707.

Dobney, K. \& G. Larson. 2006. Genetics and animal domestication: new windows on an elusive process. Journal of Zoology 269(2):261-271.

Dobzhansky, T. 1998. The birth of the genetic theory of evolution in the Soviet Union in the 1920's. In: The Evolutionary Synthesis. Perspectives on the Unification of Biology, (Eds: Mayr, E. \& W.E. Provine ) pp 229-242, Harvard University Press, Cambridge MA

Evans, L.T. 1984. Darwin's use of the analogy between artificial and natural selection. Journal of the History of Biology 17(1):113-140.

Gentry, A., J. Clutton-Brock \& C.P. Groves. 2004. The naming of wild animal species and their domestic derivatives. Journal of Archeological Science 31 (5):645-651.

Gautier, A. 1990. La domestication. Et l'homme cré ses animaux. Errance, Paris. 277 pp.

Gildenhuys, P. 2004. Darwin, Herschel, and the role of analogy in Darwin's origin. Studies in History and Philosophy of Science Part C: Studies in History 
and Philosophy of Biological and Biomedical Sciences 35(4): 593-611.

Gornall, R.J. 1983. Recombination systems and plant domestication. Biological Journal of the Linnean Society 20(4):375-383.

GREGORY, T.R. 2009. Artificial selection and domestication: modern lessons from Darwin's enduring analogy. Evolution: Education and Outreach 2(1): 5-27.

Gulevich, R.G., I.N. Oskina, S.G. Shikhevich, E.V. Fedorova \& L.N. TRUt. 2004. Effect of selection for behaviour on pituitary-adrenal axis and propiomelanocortin gene expression in silver foxes (Vulpes vulpes). Physiology and Behaviour 82(2):513-518.

Hawksworth, D.L \& M.T. Kalin-Arroyo. 1995; Magnitude and distribution of biodiversity. In: Global biodiversity assessment (Ed. Heywood, V.H.), pp. 107-191, Cambridge University Press, Cambridge.

Heiser, C.B. 1988. Aspects of unconscious selection and the evolution of domesticated plants. Euphytica 37(1):77-81.

Herbert, S. 1971. Darwin, Malthus, and selection. Journal of the History of Biology 4(1):209-217.

Huxley, T.H. 1860, The origin of species, In: Collected Essays, vol. 2, Darwiniana, London: Macmillan, 1860, pp. 71-79; Reprinted in Ruse, M. But is it Science, Amherst, NY: Prometheus Books, 1996, pp. 106-109.

JENSEN, P. 2006. Domestication-From behaviour to genes and back again. Applied Animal Behavioural Science 97(1): 3-15.

Koltsov, N. K. 1935. Hereditary molecules. Sciences of Life 5-6:4-14, reprinted in Bulletin of the Moscow Society of Naturalists (Biology) 70:75-104 (1965) (in Russian).

Kuenzl, C. \& N. SAchser. 1999. The behavioural endocrinology of domestication: a comparison between the domestic guinea pig (Cavia aperea f. porcellus) and its wild ancestor, the cavy (Cavia aperea). Hormones and Behaviour 35(1): 28-37.

KRUSKA, D. 1996. The effect of domestication of brain size and composition in the mink (Mustela vison). Journal of Zoology 239(4): 645-661.

Kukekova, A.V., G.M. Acland, I.N. Oskina, A.V. Kharlamova, L.N. Trut, K. Chase, K.L. Lark, H.N. ERB, \& G.D. AguirRe. 2006. The genetics of domesticated behaviour in canids: what can dogs and silver foxed tell us about each other? In: The dog and its genome (Eds. Ostrander, E.A.,Gicer, U. \& K. Lindblad-Toh), pp. 515-537. Cold Spring Harbor Laboratory Press, Woodbury, NY.

Kukekova, A.V., I.N. Oskina, A.V. Kharlamova, A.V., K. Chase, S.V. Temnykh, J.L. Johnson, I.V. Pivovarova, D.V. Shepeleva, A. Vladimirova, T.I. Semenova, R.G. Gulievich, S.G. SchikHEVICH, A.S. Graphodatsky, G.D. Aguirre, N. Erb, K.G. LARK, G.M. ACland \& L.N. TRUT. 2008. Fox farm experiment: hunting for behavioural genes. Gerald of VOGIS 12(1/2):50-62.

Kukekova, A.V., L.N. Trut, K. Chase, D.V. Shepeleva,
A.V. Vladimirova, A.V. Kharlamova, I.N. Oskina, A. Stepika, S.H. Klebanov, N. ERB \& G.M. ACLAND. 2007. Measurement of segregating behaviours in experimental silver fox pedigrees. Behaviour Genetics 38(2): 185-194.

Kukekova, A.V., L.N. Trut., I.N. Oskina, A.V. Kharlamova, S.G. Schikhevich, E.F. KirKness, G.D. Aguirre \& G.M. Acland. 2004. A marker set for construction of a genetic map of the silver fox (Vulpes vulpes). Journal of Heredity 95(3):185-194.

Larivière, S. \& M. Pasitschniak-Arts. 1996. Vulpes vulpes. Mammalian Species 537: 1-11.

Lindberg J., T.S. Björnerfeld, P. Saetre, K. Svartberg, B. Seehuus, M. Bakken, C. Vilà. \& E. Jazin. 2005. Selection for tameness has changed brain gene expression in silver foxes. Current Biology 15(22):R915-R916.

LLOYD, E.A. 1983. The nature of Darwin's support to the theory of natural selection. Philosophy of Science 50(1):112-129.

MacDonald, D.W. \& J.C. Reynolds. 2004. Red Fox, Vulpes vulpes Linnaeus, 1758. Least Concern, In: Canids: foxes, wolves, jackals and dogs. Status survey and conservation action plan (Eds. Sillero-Zubiri, C., Hoffmann, M. \& MacDonald, D.W.); pp. 129-136. IUCN/Species Survival Commission: Canid Specialist Group. IUCN Publications Services Unit, Cambridge.

MAYR, E. 1982. The growth of biological thought. Diversity, evolution, and inheritance. The Belknap Press of Harvard University Press, Cambridge, Massachusetts. 996 pp.

McAtee, W.L. 1936. The postulated resemblance of natural to artificial selection. Ohio Journal of Science 36(5):242-252.

Medvedev, Z.A. 1982. Nikolai Wladimirovich TimofeeffRessovsky. Genetics 100 (1):1-5.

Morey, D. 1994. The early evolution of the domestic dog. American Scientist 82 (July-August): 336-347.

Nicholls, H. 2009. Darwin 200: a flight of fancy. Nature 457(7231):780-781.

NowAK, R.M. 1999. Walker's mammals of the world. Vol. 1. The Johns Hopkins University Press, Baltimore \& London. $\mathrm{x}+838$ pp.

O'Regan, H.J. \& A.C. Kitchener. 2005. The effects of captivity on the morphology of captive, domesticated and feral mammals. Mammal Review 53(3\&4):215-230.

Otтo, S.P. \& N.H. Barton. 2001. Selection for recombination in small populations. Evolution 55(10):1921-1931.

PAterson, A. 2002. What has QTL mapping taught us about plant domestication? New Phytologist 154 (3):591-608.

Pearl, R. 1917. The selection problem. American Naturalist 51(602):65-91.

Popova, N. K. 2006. From genes to aggressive behaviour: the role of serotonergic system. BioEssays 28(5):495-503.

Porter, D.M. 2004. A short trip through the world of 
Alfred Russel Wallace. BioScience 54(4):594595.

Prasolova, L.A. \& L.N. Trut. 1993. The effect of the star gene on the rate of melanoblast migration in embryos of silver fox Vulpes vulpes. Doklady Akademii Nauk 329(6):787-789.

Price, E.O. 1984. Behavioural aspects of animal domestication. Quarterly Review of Biology 59(1):1-32.

Price, E.O. \& J.A. King.1968. Domestication and adaptation. In: Adaptation of domestic animals (Ed. Hafez, S.E.), pp. 34-45. Lea \& Febiger, Philadelphia.

Pringle, P. 2008. The murder of Nikolai Vavilov: The Story of Stalin's persecution of one of the great scientists of the twentieth century. Simon \& Schuster, New York, 370 pp.

RATNER, S.C. \& R. BoICE. 1975. Effects of domestication on behaviour. In: The behaviour of domestic animals, $3^{\text {rd }}$ Edit. (Ed: Hafez, S.E.), pp. 3-19. Williams \& Williams, Baltimore.

Rees, H. \& P.J. DALe. 1974. Chiasmata and variability in Lolium and Festuca populations. Chromosoma 47(3):335-351.

Richards, R.A. 1997. Darwin and the inefficacy of artificial selection. Studies in History and Philosophy of Science Part A 28(1): 75-97.

Richards, R.A. 1998. Darwin, domestic breeding and artificial selection. Endeavour 22(3): 106-109.

Rindos, D. 1980. Symbiosis, instability and the origins and spread of agriculture: a new model. Current Anthropology 21(6):751-772.

Ross-IbARRA, J. 2004. The evolution of recombination under domestication: a test of two hypotheses. The American Naturalist 163(2):106-112.

Ruse, M. 1975. Charles Darwin and artificial selection. Journal of the History of Ideas 36(2):339-350.

SARKAR, S. 2008. Wallace and natural selection. Resonance 13(3):236-244

SECORD, J.A. 1981. Nature's fancy: Charles Darwin and the breeding of pigeons. Isis 72(2):163-186.

Shaler, N.S. 1908. Domesticated animals their relation to man and to his advancement in civilization. Charles Scribner's Sons, New York.

ShI, L., L.TANG, K. MA \& C. MA. 1988. Synaptonemal complex formation among supernumerary B chromosomes: an electron microscopic study on spermatocytes of Chinese raccoon dogs. Chromosoma 97:178-183.

Smarti, J., \& N.W. Simmonds. 1995. Evolution of crop plants. Longman, Harlow, Essex. pp. 531.

SoL, D. 2008. Artificial selection, naturalization, and fitness: Darwin's pigeons revisited. Biological Journal of the Linnean Society 93(4):657-665.

Soyfer, V.N. 2001. The consequences of political dictatorship for Russian science. Nature Reviews Genetics 2(9):723-729.

SPenCER, H. 1893. The inadequacy of "Natural Selection." Contemporary Review 63 (326): Feb. 153-166, and 63 (327), March,439-456.

STERrett, S.G. 2002. Darwin's analogy between artificial and natural selection: how does it go? Studies in History and Philosophy of Science Part C: Studies in History and Philosophy of Biological and Biomedical Sciences 33(1):151-168.

Stewart, B. \& P.G. Tait. 1886. The unseen universe or physical speculations on a future state. MacMillan, New York.

Switonski, M., I. Gustaffson, K. Höjer \& L. Plöen. 1987. Synaptonemal complex analysis of the B-chromosomes in spermatocytes of the silver fox (Vulpes fulvus Desm.). Cytogenetics and Cell Genetics 45(1):84-92.

TAIT, P.G. 1871. Artificial selection. MacMillan's Magazine 25:416-421.

TRUT, L.N. 1988. The variable rates of evolution transformations and their parallelism in terms of destabilizing selection. Journal of Animal Breeding and Genetics 105(1):81-90.

TRuT, L.N. 1999. Early canid domestication: the farmfox experiment. American Scientist 87(MarchApril):160-169.

Trut, L.N., A.V. Kharlamova, A.V. Kukekova, G.M. Acland, D.R. Carrier, K. Chase \& K.G. Lark. 2006. Morphology and behaviour: are they coupled at the genome level? In: The Dog and its Genome (Eds. Ostrander, E.A., U.Gicer \& K. Lindblad-Toh), pp. 81-93. Cold Spring Harbor Laboratory Press, Woodbury.

Trut, L.N., A.L. Markel, P.M. Borodin, S.V. Argutinskaya, I.K. ZaKharov \& V.K. ShumnY. 2007. To the 90th Anniversary of Academician Dmitry Konstantinovich Belyaev (1917-1985). Russian Journal of Genetics 43(7):717-720.

Trut, L., Oskina, I. \& A. Kharlamova. 2009. Animal evolution during domestication: the domesticated fox as a model. BioEssays 31(3):349-360.

Trut, L.N., I.Z. Plyusnina \& I.N. Oskina. 2004. An experiment on fox domestication and debatable issues of evolution of the dog. Russian Journal of Genetics 40(6):644-655.

Vorzimmer, P.J. 1969a. Darwin's questions about the breeding of animals (1839). Journal of the History of Biology 2(1):269-281.

VorzIMMER, P.J. 1969b. Darwin, Malthus, and the theory of natural selection. Journal of the History of Ideas 30(5):527-542.

VuCINICH, A. 1988. Darwin in Russian thought. University of California Press, Berkeley. 468 pp.

Wallace, A.R. 1889. Darwinism. MacMillan, London \& New York. 512 pp.

WilnER, E. 2006. Darwin's artificial selection as an experiment. Studies in History and Philosophy of Biological and Biomedical Sciences 37(1):2640.

Wright, C. 1872. Letter to Charles Darwin. August 29, 1872. Reprinted in: Letters of Chauncey Wright, with some account of his life by James Bradley Thayer, 1878, pp. 240-246. Cambridge, Massachusetts.

Yudkin, D.V., V.A. Trifonov, A.V. Kukekova, N.V. Vorobieva, N.V. Rubtsova, F. YANG, G.M. Acland, M.A. Ferguson-Smith \& A.S. Graphodatsky. 
2007. Mapping of KIT adjacent sequences on canid autosomes and $\mathrm{B}$ chromosomes. Cytogenetic and Genome Research 116 (1):100-103.

ZaKharov, I.A. 2005. Nikolai I Vavilov (1887-1943). Journal of Biosciences 30(3): 299-301.

Zeder, M.A., E. Emshwiller, B.D. Smith \& D.G.
BRADLEy. 2006. Documenting domestication: the intersection of genetics and archaeology. Trends in Genetics 22(3): 139-155.

ZOHARY, D. 2004. Unconscious selection and the evolution of domesticated plants. Economic Botany 58(1):510. 